\title{
THE BALANCED REGIONAL DEVELOPMENT VIA CPSEs IN INDIA
}

\author{
Dr. AJAB SINGH \\ Assistant Professor, Department of Commerce, Maharana Pratap Government Degree College,
}

Sikandra Rao, Hathras, Uttar Pradesh, India

\begin{abstract}
Central Public Sector Enterprises CPSEs have made versatile and important contributions to the country's economy and have been successful to a great extent by fulfilling its objectives. It has been reflected from the study that in the last three years, 'Gross Block' increase in most of the states. It increased more than 4 in descending order in Chhattisgarh, West Bengal, Delhi, Karnataka, and Madhya Pradesh and between 5 to 6 in the same order in Andhra Pradesh, Tamil nadu, Orissa, and Uttar Pradesh. Increase in Other and Unallocated were 14 to 17 and have made significant contributions towards achieving self-sufficiency in the country in the various economic sectors as well as balanced regional development in the nation. it has been discussed the o one dimension of balanced regional development through setting up of Central Public Sector Enterprises CPSEs in India in terms of gross block Investment in CPSEs in several States Union Territories for balanced industrial growth in the backward regions. This paper examines the trends of Gross Block of Central Public Sector Enterprises in several states of India, with a view to wit the overall contribution of these CPSEs in balanced regional development in terms of financial investment in the nation. Using current PE surveys, MOHIPE annual reports, Economic Surveys, etc., we firstly, highlights the Current Status of CPSEs in India along with the Industrially Backward States and Union Territories. Secondly, it has been studied the trends of Gross Block of CPSEs in various Industrially Backward States and Union Territories of India. Finally, an analysis is made through Comparative Statistics of Gross Block in Industrially Back Ward, Developing and Developed States of India in CPSEs and other factors also are analyzed.
\end{abstract}

KEYWORDS: Balanced Regional Development, CPSEs \& Gross Block

Received: May 07, 2019; Accepted: May 28, 2019; Published: Jun 17, 2019; Paper Id.: IJBMRAUG20192

\section{INTRODUCTION}

Central Public Sector Enterprises (CPSEs) in India represent an economic philosophy which has evolved as a result of democratic forces and social awareness generated for social justice at the time of the independence movement. It is clear that if there was no public sector, the magnificent structure of the industrial sector would not have been created. I would have but I must admit that if the public undertaking introduced its full efficiency, then the country would have progressed ahead of the race. As far as the future of public undertakings is concerned, its future is very bright due to the rapid economic and industrial development of the country, but the point of attention is that the size of the public undertakings, the pace of development, the way of working, etc. It should be better if the working units are strengthened financially along with the extension work of the Public Enterprises. It is worth noting that by selling the share capital of public undertakings to the public, the government has created an environment for these enterprises to operate on a business basis and has developed the basis for continuous improvement of performance through arrangement of the Memorandum of Understanding (MOU). 
The central public sector enterprises (CPSEs) have been playing a significant role in the rapid and balanced economic growth of our country. Without the public sector, India would not be among the front rankers in the world, which she is today, in the sphere of industry and technology. These enterprises function in our country as an active or social agent for social change. They now clearly and unambiguously emerged as a major factor in international economic life. They are moving forward covering large areas of economic activity and strengthening their position in the crucial segments of the Indian economy. To the point of view of lead to a more balanced growth in the country, it had been adopted the planning and a strategy of State-led industrialisation. It was considered that inter-State disparities would be minimised gradually. Plans and policies were designed to facilitate more investments in the relatively backward areas. Notwithstanding, socioeconomic variations across States exist over a prolonged period of time. Since the very beginning of existence, the Department of Public Enterprises has been working as a nodal agency for the development and management of CPSEs. These CPSEs have made progress in several areas of economy. CPSEshave been set up to serve the broad macro-economic objectives of higher economic growth, self- sufficiency in production of goods and services, long term equilibrium in balance of payments and low and stable prices besides meeting certain socio-economic obligations. While there were only five CPSEs with a total investment of Rs. 29 crore at the time of the First Five Year Plan, there were 339 CPSEs with a total investment of Rs. 13,73,412crore as on $31^{\text {st }}$ March, 2018.

Table 1: Current Status of CPSEs in India

\begin{tabular}{|c|l|c|c|c|c|c|c|c|c|c|}
\hline \multirow{2}{*}{$\begin{array}{c}\text { SI. } \\
\text { No. }\end{array}$} & \multicolumn{9}{|c|}{ Total Entegories } & \multicolumn{2005}{|c|}{} & $\mathbf{2 0 0 7}$ & $\mathbf{2 0 0 8}$ & $\mathbf{2 0 0 9}$ & $\mathbf{2 0 1 0}$ & $\mathbf{2 0 1 4}$ & $\mathbf{2 0 1 5}$ & $\mathbf{2 0 1 6}$ & $\mathbf{2 0 1 8}$ \\
\hline 1. & Operating Enterprises & 227 & 217 & 214 & 213 & 217 & 234 & 235 & 244 & 257 \\
\hline 2. & $\begin{array}{l}\text { Enterprises which are yet to } \\
\text { commence commercial operation }\end{array}$ & 10 & 30 & 28 & 33 & 32 & 56 & 63 & 76 & 82 \\
\hline & Sub-Total & $\mathbf{2 3 7}$ & $\mathbf{2 4 7}$ & $\mathbf{2 4 2}$ & $\mathbf{2 4 6}$ & $\mathbf{2 4 9}$ & $\mathbf{2 9 0}$ & $\mathbf{2 9 8}$ & $\mathbf{3 2 0}$ & $\mathbf{3 3 9}$ \\
\hline 3. & Insurance Companies & 6 & 7 & 7 & 7 & 7 & 7 & 7 & 7 & 7 \\
\hline 4. & Financial Institutions & 2 & & & & & & & & \\
\hline & Grand Total & $\mathbf{2 4 5}$ & $\mathbf{2 5 4}$ & $\mathbf{2 4 9}$ & $\mathbf{2 5 3}$ & $\mathbf{2 5 6}$ & $\mathbf{2 9 7}$ & $\mathbf{3 0 5}$ & $\mathbf{3 2 7}$ & $\mathbf{3 4 6}$ \\
\hline
\end{tabular}

Source: Department of Public Enterprises, Ministry of Heavy Industries \& Public Enterprises, Government of India.

Table1 highlights the current position of CPSEs in India. In aforesaid presentation, it has been shown the operating enterprises, enterprises which are yet to commence commercial operation, Insurance Companies, and Financial Institutions. It is obvious that the number of public enterprises falling within the scope of the Survey as on 31March,2005 is 237 (excluding 6 Insurance Companies and 2 Financial Institutions). In the year 2004-05, six CPSEs viz., Bengal Immunity Ltd., Manipur State Drugs and Pharmaceuticals Ltd., Maharashtra Antibiotics \& Pharmaceuticals Ltd., Smith Stani street \& Pharmaceuticals Ltd., ET \&T Ltd. and National Industrial Development Corporation Ltd. have been closed either due to the order of BIFR or a decision taken by the related administrative Ministries.

In addition to, Bhilai Oxygen Ltd. has been wound up on the recommendation of its Holding company (Steel Authority of India Ltd.). UP Drugs and Pharmaceuticals Ltd. has been taken over by the Government of Uttar Pradesh in pursuance to the revival package approved by the BIFR. Here Upon, the names of all these 8 enterprises have not been listed in the Public Enterprises Survey 2004-05. Under the year 2004-05, 3 new CPSEs, viz., BEL Optronic Devices Ltd., Indian Strategic Petroleum Reserves Ltd. and Kumarakruppa Frontier Hotels Pvt. Ltd. have been included in the Survey Report as per the information received from concerned administrative Ministries/ Departments.

There were 320 CPSEs in the year 2015-16 (as on 31 ${ }^{\text {st }}$ March 2016) in comparison to 298 CPSEs in previous year. It has been added to 29 new enterprises in the list of CPSEs, namely, IIFCL Projects Ltd., IIFCL Asset Management Co. 
Ltd., NBCC Services Ltd., Petronet CCK Ltd, ONGC Mangalore Petrochemicals Ltd., Bihar Megapower Ltd, Bihar Infrapower Ltd., BPCL-KIAL Fuel Pvt. Ltd. Chhattisgarh East Railways Ltd., Chhattisgarh Mega Steel Co. Ltd. Deoghar Infra Ltd., Dingchang Transmission Ltd., IRCON Shivpuri Guna Tollway Ltd., Jharkhand Kolhan Steel Ltd, Jharkhand Infrapower Ltd., Khargoane Transmission Ltd., Kohima-Mariani Transmission Ltd., Medinipur-Jeerat Transmission Ltd., NMDC Steel Ltd., NER - II Transmission Ltd., NRSS XXXVI Transmission Ltd., North Karanpura Transco Ltd., Patratu Vidyut Utpadan Nigam Ltd., NBCC Engineering and Consultancy Ltd., POWER GRID Parli Transmission Ltd., POWERGRID Southern Interconnector Transmission System Ltd., POWER GRID Warora Transmission Ltd, Yule Electrical Ltd. and Yule Engineering Co. Ltd. Furthemore, Seven enterprises were closed or merged with other CPSEs in the year 2015-16. Three CPSEs, viz., Chhattisgarh-WR Transmission Ltd., Raipur Rajanandgaon Warora Transmission Ltd., and Sipat Transmission Ltd. closed due to transfer to M/s. Adani Transmission Ltd. Two CPSEs, SAIL Jagdishpur Power Plant Ltd. and SAIL Sindri Projects Ltd. were closed by the order of Board of Steel Authority of India Ltd.; Bharat Bhari Udyog Nigam Ltd. and Irrigation \& Water Resources Finance Corporation Ltd. merged with Braithwaite Burn \& Jessop Construction Ltd. and India Infrastructure Finance Company Ltd. consecutively by the order of Government. In this year, 4 CPSEs, viz., Neyveli Lignite Corporation Ltd., National Building Corporation Ltd., Uchahar Transmission Ltd. and Vizag Transmission Ltd. have been renamed as NLC India Ltd., NBCC India Ltd., Powergrid Unchahar Transmission Ltd and Powergrid Vizag Transmission Ltd. Consecutively(PES 2015-16).

\section{INDUSTRIALLY BACKWARD STATES AND UNION TERRITORIES IN INDIA}

The Industrial Policy of 1991, the license system for commencing new industries has been simplified. Mostly emphasis has been given on the development of infrastructural facilities. States are granting concessions to attract capital and locate industries in backward areas. In the study concerned, the Eighth Schedule of Income Tax Act 1961(as amended by the Finance Act 2010) is based for identifying the industrially backward States and Union Territories in India. The section 80-IA(2)(iv )(b) of Eighth Schedule of this act, it has been given the name of those States and Union Territories which are industrially backward. They are as follows:

Table 2: Industrially Backward States and Union Territories in India

\begin{tabular}{|c|l|c|l|}
\hline S. No. & Backward States & S. No. & \multicolumn{1}{|c|}{ Backward States } \\
\hline 1. & Arunachal Pradesh & 9. & Nagaland \\
\hline 2. & Assam & 10. & Sikkim \\
\hline 3. & Goa & 11. & Tripura \\
\hline 4. & Himachal Pradesh & 12. & Andaman and Nicobar Islands \\
\hline 5. & Jammu and Kashmir & 13. & Dadra and Nagar Haveli \\
\hline 6. & Manipur & 14. & Daman and Diu \\
\hline 7. & Meghalaya & 15. & Lakshadweep \\
\hline 8. & Mizoram & 16. & Pondicherry \\
\hline
\end{tabular}

Source: https://incometaxindia.gov.in

\section{REVIEW OF LITERATURE}

The Industrial Policy Resolution, April 1956 stated that "In order that industrialization may benefitthe economy of the country as a whole, it is important that disparities in levels of development between different regions should be progressively reduced. The lack of industries in different parts of the country is very often determined by factors such as the availability of the necessary raw materials or other natural resources. A concentration of industries in certain areas has also been due to the ready availability of power, water supply and transport facilities which has been developed there. It is 
one of the aims of national planning to ensure that these facilities are steadily made available to areas which are at present lagging behind industrially or where there is greater need for providing opportunities for employment provided the location is otherwise suitable. Only by securing a balanced and coordinated development of the industrial and the agricultural economy in each region can be the entire country attains higher standards of living".

The Industrial Policy Resolution of February 1973 reiterated that "in the implementation of the licensing policy Government will ensure that licensing decisions confirm to the growth profile of the Plan and the techno-economic and social considerations such as economies of scale, appropriate technology, balanced regional development and development of backward areas are fully reflected. Government's policy will continue to encourage competent small and medium entrepreneurs in all industries. Such entrepreneurs will be preferred vis-à-vis the larger industrial houses and foreign companies in the setting up of new capacity. Licensing policy will seek to promote production of companies in the setting up of new capacity. Licensing policy will seek to promote production of ancillaries, wherever feasible and appropriate, in the medium or small scale sector. Cooperatives and small and medium entrepreneurs will be encouraged to participate in the production of mass consumption goods with the public sector also taking an increasing role. Other investors will be allowed to participate in the production of mass consumption goods only if there are special factor such as sizable economies of scale resulting in reduced prices, technological improvements, large investment requirements, substantial export possibilities or as part of modernization. Government also intends to enlarge and intensify a variety of positive measures designed to promote the growth of small and medium entrepreneurs".

The Industrial Policy Resolution of December 1977 further envisaged the industrial location policy to become an effective instrument of balanced regional industrial development. The policy stated that "the Government attaches great important to balanced regional development of the entire country so that disparities in levels of development between different regions are progressively reduced. Government have noted with concern that most of the industrial development that has taken place in our country since Independence has been concentrated around the metropolitan areas and large cities. The result has been a rapid deterioration in the living conditions especially for the working classes in the larger cities and attendant problems of slums and environmental pollution."'In order to secure balanced regional development it was decided by Government that industrial licenses would not be issued to new industrial units for location within certain limits of large metropolitan cities having a population of more than 1 million and urban areas with a population of more than 5 lakhs as per the 1971 census". State Governments and financial institutions will be requested to deny support to new industries in these areas such as those which do not require an industrial license. The Government of India would also consider providing assistance to large existing industries which want to shift from congested metropolitan cities to approved locations in backward areas. For dispersal of industries and setting of units in industrially backward areas Government also provided special concessions and facilities.

The Industrial Policy Statement of July 1980, which is based as the Industrial Policy Resolution of 1956, spells out the following socio-economic objectives: (i) Optimum utilization of installed capacity; (ii) Maximum production and achieving higher productivity; (iii) Higher employment generation; (iv) Correction of regional imbalances; (v) Strengthening of the agricultural base through agro-based industries and promotion of optimum inter-sectoral relationship; (vi) Promotion of export-oriented industries; (vii) Promotion of economic federalism through equitable spread of investment and dispersal of returns; and (viii) Consumer protection against high prices and bad quality. 
In 1987, at the instance of Central Board of Direct Taxes, National Institute of Public Finance and Policy, conducted a study to evaluate the impact of fiscal concessions on development of backward areas. The study concluded that while the fiscal incentives for backward areas development did successfully promote industrial dispersal, the criterion of identifying backward areas in a State with reference to its development indicators rather than all India norms favoured developed States. The study, however, suggested enlargement of the scope of tax incentives for new industrial establishments in Income Tax Act. This was the rationale for introduction of full tax holiday for the initial five years for the industrial policies in backward States or Union Territories specified in Eighth Schedule. It is said in Statement on Industrial Policy, July 1991 that, "the public sector has been central to our philosophy of development. In the pursuit of our development objectives, public ownership and control in critical sectors of the economy has played an important role in preventing the concentration of economic power, reducing regional disparities and ensuring that planned development serves the common good".

Therefore, continuous efforts have been made to overcome regional disparities in various Industrial policy statements through Central Public Sector Enterprises in India.

\section{NEED OF THE STUDY}

New economic policy and its continuation, the Indian economy has undergone significant improvement and now is one of the fastest growing economies in the world. The famous BRIC report predicts that India will grow as the second largest economy by 2050. It has been adopted consistently the policy measures for improving the regional imbalances through CPSEs in India. Wherefrom, I compelled to analyze the investment in 'Gross Block' of operating CPSEs in several states of India in changing scenario in recent nearly FY 1984-85 TO 2015-16 and come to know the new barriers to sustain the regional imbalances of various states via CPSEs in the country.

\section{OBJECTIVES OF THE STUDY}

It is important to evaluate that in the changing environment of India of 21 st Century, to which extent the investment in 'Gross Block' of CPSEs in various industrially backward states of the country has actually been improved in the study period. This exploratory exercise endeavours to document the long-term trends in some aspects to the 'Gross Block' of CPSEs for the period during 1984-85 to 2015-16. In particular, it has been tried to examine the trend of Gross Block' of CPSEs in India. There has been analyzed the 'Gross Block' in Industrially Back Ward, Developing and Developed States Comparatively. To the point of view of evaluation, various measures have been taken into account.

\section{RESEARCH METHODOLOGY}

It has been made an attempt to analyze both quantitative and qualitative data based on exploratory research in the present study. With the view to achieve the objectives and results of the study concerned, secondary data have been collected on all India basis by using Public Enterprises Surveys, annual reports of Ministry of Heavy Industries and Public Enterprises, Government of India, Economic Surveys, Ministry of Finance, DEA, E D, Government of India. Furthermore, reference books, policy papers and articles, etc.

\section{Balanced Regional Development through CPSES in India}

It is commonly seen that private sector does not want to invest in backward regions that lack infrastructure and other basic facilities such as power, roads, telecommunication, skilled labour etc. CPSEs set up large projects in these areas 
and spend huge cost to develop such areas. In this manner CPSEs assist to achieve balanced regional growth.

\section{State-Wise Distribution of Gross Block}

Central Public Sector Enterprises (CPSEs) have invested funds in terms of gross block for the productivity in diverse states. The funds have been invested as per the requirement of the CPSEs and the balance regional development in the country. In absolute terms, there has generally been increase in investments in most states of India. Gross block in CPSEs in entire states of the country were $\square 47323.27$ Crore on 31st March 1985, which increased by 42.8 times to $\square$ 2026315 crore on 31st March 2016. The state wise distribution of investment in terms of gross block has been displayed in upcoming Table 3 as follows:

Table 3: State-Wise Distribution of Gross Block of CPSEs in India

( in ? Crore)

\begin{tabular}{|c|c|c|c|c|c|c|c|c|c|c|}
\hline $\begin{array}{c}\text { S. } \\
\text { No. }\end{array}$ & States/Union Territories & $1984-85$ & $1996-97$ & $2007-08$ & 2008-09 & 2009-10 & $2012-13$ & 2013-14 & 2014-15 & $2015-16$ \\
\hline 1. & Andhra Pradesh & 4058.78 & 19486.16 & 58967.05 & 66260.94 & 79459.24 & 100010.59 & 127495.15 & 100010.59 & 101144.5 \\
\hline 2. & Anunachal Pradesh & 0 & 1489.20 & 4876.03 & 6161.31 & 3240.90 & 11104.80 & 12071.08 & 13613.41 & 15123.25 \\
\hline 3. & Assam & 2451.15 & 12448.89 & 36293.76 & 42291.42 & 52748.28 & 78800.49 & 71394.67 & 78800.49 & 86812.68 \\
\hline 4. & Bihar & 5833.77 & 19982.51 & 20894.81 & 25611.49 & 29148.38 & 60724.30 & 55773.01 & 60724.30 & 64517.29 \\
\hline 5. & Chhattisgarh & 0 & 0 & 27981.48 & 34036.89 & 38584.17 & 82164.08 & 70380.48 & 82164.08 & 92206.91 \\
\hline 6. & Goa & 17.79 & 144.57 & 950.16 & 3099.52 & 1427.16 & 1602.45 & 1769.04 & 1602.45 & 1839.38 \\
\hline 7. & Gujrat & 1771.77 & 20092.87 & 51356.04 & 54723.26 & 61576.26 & 87334.13 & 76382.83 & 87334.13 & 88107.8 \\
\hline 8. & Haryana & 411.80 & 4352.25 & 25679.06 & 41668.21 & 37378.49 & 49318.02 & 47429.75 & 49318.02 & 51993.23 \\
\hline 9. & Himachal Pradesh & 211.05 & 4720.54 & 21906.88 & 15774.83 & 28350.25 & 38957.77 & 37634.46 & 38957.77 & 40842.72 \\
\hline 10. & Jharkhand & 0 & 0 & 24073.19 & 26263.92 & 30460.94 & 48401.55 & 42693.36 & 48401.55 & 49270.84 \\
\hline 11. & Jammu \& Kashmir & 48.28 & 6413.36 & 14331.61 & 15674.88 & 16162.18 & 24500.07 & 23528.67 & 24500.07 & 25554.96 \\
\hline 12. & Kamataka & 1327.53 & 6439.48 & 35964.17 & 37862.09 & 40846.02 & 72457.90 & 65817.26 & 72457.90 & 88664.47 \\
\hline 13. & Kerala & 831.22 & 3991.76 & 20746.25 & 23378.47 & 26601.98 & 37825.79 & 33865.88 & 37825.79 & 43354.07 \\
\hline 14. & Madhya Pradesh & 5396.12 & 21503.52 & 40732.50 & 43772.53 & 46546.29 & 81991.08 & 74457.85 & 81991.08 & 90882.57 \\
\hline 15. & Maharahashtra & 7601.81 & 54854.07 & 15301735 & 171144.43 & 188850.84 & 323654.18 & 297162.52 & 323654.18 & 177969.78 \\
\hline 16. & Manipur & 131.32 & 148.31 & 333.48 & 341.20 & 381.50 & 685.02 & 520.74 & 685.02 & 937.04 \\
\hline 17. & Meghalaya & 1.89 & 53.43 & 257.00 & 330.86 & 319.54 & 344.89 & 322.93 & 344.89 & 365.07 \\
\hline 18. & Mizoram & - & 30.03 & 381.13 & 372.04 & 407.50 & 1237.89 & 886.13 & 1237.89 & 1486.17 \\
\hline 19. & Nagaland & 72.98 & 465.36 & 1096.51 & 1146.46 & 1139.46 & 1257.89 & 1177.24 & 1257.89 & 1241.85 \\
\hline 20. & Orissa & 2997.74 & 17101.40 & 40111.01 & 44044.50 & 48010.81 & 108095.85 & 102321.04 & 108095.85 & 122943.67 \\
\hline 21. & Punjab & 563.62 & 2077.85 & 11224.73 & 11893.40 & 12914.23 & 19493.58 & 17828.97 & 19493.58 & 20006.89 \\
\hline 22. & Rajasthan & 647.62 & 6065.94 & 22012.32 & 25660.96 & 25438.13 & 39308.77 & 33999.75 & 39308.77 & 44397.43 \\
\hline 23. & Sikkim & - & 241.13 & 3311.15 & 3484.25 & 3448.08 & 4432.81 & 4276.52 & 4432.81 & 4521.41 \\
\hline 24. & Tamilnadu & 2548.66 & 13539.28 & 66445.14 & 65144.13 & 83576.62 & 124150.77 & 120166.40 & 124150.77 & 123445.76 \\
\hline 25. & Tripura & 93.38 & 830.54 & 2041.46 & 3959.38 & 2598.32 & 6944.05 & 6240.71 & 6944.05 & 7426.54 \\
\hline 26. & Telangana & 0 & 0 & 0 & 0 & 0 & 11660.58 & 11660.58 & 11660.58 & 16747.69 \\
\hline 27. & Uttar Pradesh & 2532.77 & 20767.92 & 57232.99 & 66192.19 & 72992.09 & 118576.46 & 109549.02 & 118576.46 & 130550.88 \\
\hline 28. & Uttaranchal & - & 0 & 17040.22 & 18401.38 & 20963.39 & 26513.79 & 25250.84 & 26513.79 & 28224.04 \\
\hline 29. & West Bengal & 3345.37 & 18677.33 & 43817.25 & 49806.89 & 55704.42 & 91564.26 & 85464.22 & 91564.26 & 92085.37 \\
\hline \multicolumn{11}{|c|}{ Union Territories } \\
\hline 1. & Andaman \& Nicobar Islands & 6.21 & 27.10 & 269.77 & 302.23 & 325.46 & 441.46 & 2327.26 & 441.46 & 454.36 \\
\hline 2. & Chandigarh & 3.52 & 289.30 & 231.50 & 234.96 & 256.85 & 649.09 & 559.79 & 649.09 & 674.24 \\
\hline 3. & Dadra Nagarhavli & 0 & 0 & 73.66 & 78.28 & 0 & 378.03 & 358.85 & 378.03 & 409.15 \\
\hline 4. & Daman and Diu & 0 & 0 & 3.03 & 7.55 & 0 & 231.00 & 174.75 & 231.00 & 246.26 \\
\hline 5. & Delhi & 1238.83 & 15014.81 & 24470.05 & 26496.55 & 42029.12 & 63435.78 & 61748.26 & 63435.78 & 91524.47 \\
\hline 6. & Lakshadweep & 0 & 0 & 4.11 & 6.16 & 0 & .00 & .01 & .00 & 0 \\
\hline \multirow[t]{2}{*}{7.} & Pondicherry & 7.66 & 30.40 & 292.28 & 298.31 & 332.20 & 389.50 & 283.39 & 389.50 & 410.67 \\
\hline & Others and Unallocated & 3170.43 & 13082.21 & 33811.66 & 51864.79 & 77721.85 & 185649.03 & 144938.54 & 185649.03 & 319931.9 \\
\hline Grand Total & All India & 47323.27 & 284361.52 & 862230.79 & 977802.96 & 1129941.66 & 1906796.31 & 1756530.80 & 190679631 & 202631531 \\
\hline
\end{tabular}

Note and Source: Gross Block encompasses capital- work-in-progress (including intangible assets). There are 29 States and 7 Union Territories in India. Arunachal Pradesh, Mizoram, Goa, Chhattisgarh, Uttaranchal, Jharkhand, and Telangana had achieved statehood on the February $20^{\text {th }} 1987$, February $20^{\text {th }} 1987$, May $30^{\text {th }} 1987$, November $1^{\text {st }} 2000$, November $9^{\text {th }} 2000$, November $15^{\text {th }} 2000$, and June $2^{\text {nd }} 2014$, respectively. Due to division of Andhra Pradesh in two states, Telangana and a residual Andhra Pradesh came in to existence. The data are sourced from Department of Public Enterprises, Public Enterprises Survey, 1984-85 to 2015-16. 


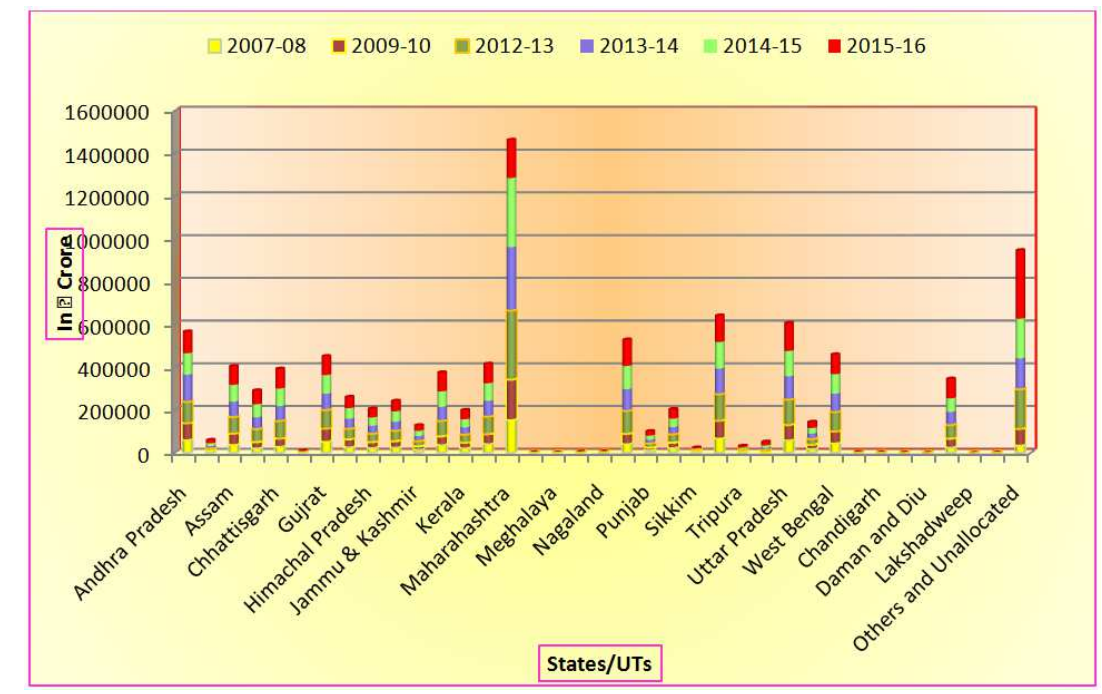

\section{Source: Author's elaboration, based on Public Enterprises Survey 2007/08 to 2015/2016, Govt. of India}

Figure 1: Share of States/ UTs in Gross Block of CPSEs (In arore)

Table 3 and Figure 1 depict the States/Union Territories wise allocation of gross block in terms of rupees crore in Indian CPSEs since 1984-85 to 2015-16. While we think the position of gross block in Indian CPSEs in backward states/ Union Territories, then it is clear that gross block increase in various years in these States/Union Territories. In the year 1996-97, gross block in CPSEs in backward States viz., Arunachal Pradesh, Assam, Goa, Himachal Pradesh, Jammu and Kashmir, Manipur, Meghalaya, and Mizoram were?1489.2 Crore, ?12448.89 Crore, ?144.57 crore, ?4720.54 crore, ? 6413.96 crore, ? 148.31 crore, ?53.43 crore, and ?30.03 crore, respectively that as a result of increase in the year 2015-16,

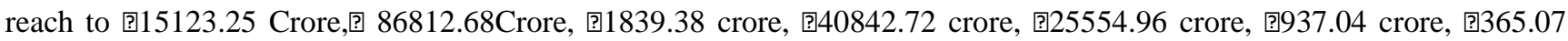
crore, and 1486.17 crore, respectively. Similarly, gross block in Indian CPSEs in the five States/Union Territories namely, Nagaland, Sikkim, Tripura, Andaman and Nicobar Islands, and Pondicherry were ?465.36 Crore, ?241.13 Crore, ?830.54 Crore, ?27.1 Crore, and ?30.4 Crore, consecutively in the year 1996-97, which increased to ?1241.85 Crore, ?4521.41 Crore, ?7426.54 Crore, ?454.36 Crore, and ?410.67 Crore, respectively in the year 2015-16. Furthermore, gross block in CPSEs extended in Dadra and Nagar Haveli, and Daman and Diu during several years.

Gross block of CPSEs in several States/ Union Territories of India in terms of percentage for the year 1984-85 to 2015-16 are presented as follows:

Table 4: State-Wise Share in Gross Block of CPSEs in India

(\% Share in Total Gross Block)

\begin{tabular}{|c|l|c|c|c|c|c|c|c|c|c|}
\hline $\begin{array}{c}\text { S. } \\
\text { No. }\end{array}$ & States/Union Territories & $\begin{array}{c}\mathbf{1 9 8 4 -} \\
\mathbf{8 5}\end{array}$ & $\begin{array}{c}\mathbf{1 9 9 6} \\
\mathbf{9 7}\end{array}$ & $\begin{array}{c}\mathbf{2 0 0 7 -} \\
\mathbf{0 8}\end{array}$ & $\begin{array}{c}\mathbf{2 0 0 8 -} \\
\mathbf{0 9}\end{array}$ & $\begin{array}{c}\mathbf{2 0 0 9 -} \\
\mathbf{1 0}\end{array}$ & $\begin{array}{c}\mathbf{2 0 1 2 -} \\
\mathbf{1 3}\end{array}$ & $\begin{array}{c}\mathbf{2 0 1 3}- \\
\mathbf{1 4}\end{array}$ & $\begin{array}{c}\mathbf{2 0 1 4 -} \\
\mathbf{1 5}\end{array}$ & $\begin{array}{c}\mathbf{2 0 1 5}- \\
\mathbf{1 6}\end{array}$ \\
\hline 1. & Andhra Pradesh & 8.58 & 6.85 & 6.85 & 6.78 & 7.03 & 7.33 & 7.26 & 5.24 & 4.99 \\
\hline 2. & Arunachal Pradesh & - & 0.52 & 0.57 & 0.63 & 0.29 & 0.71 & 0.69 & 0.71 & 0.75 \\
\hline 3. & Assam & 5.18 & 4.38 & 4.38 & 4.33 & 4.67 & 4.09 & 4.06 & 4.13 & 4.28 \\
\hline 4. & Bihar & 12.33 & 7.03 & 2.42 & 2.62 & 2.58 & 2.8 & 3.18 & 3.18 & 3.18 \\
\hline 5. & Chhattisgarh & - & - & 3.25 & 3.48 & 3.41 & 3.89 & 4.01 & 4.31 & 4.55 \\
\hline 6. & Goa & 0.04 & 0.05 & 0.11 & 0.32 & 0.13 & 0.1 & 0.1 & 0.08 & 0.09 \\
\hline 7. & Gujrat & 3.74 & 7.07 & 5.97 & 5.60 & 5.45 & 4.49 & 4.35 & 4.58 & 4.35 \\
\hline 8. & Haryana & 0.87 & 1.53 & 2.98 & 4.26 & 3.31 & 2.88 & 2.7 & 2.59 & 2.57 \\
\hline 9. & Himachal Pradesh & 0.45 & 1.66 & 2.54 & 1.61 & 2.51 & 2.21 & 2.14 & 2.04 & 2.02 \\
\hline
\end{tabular}




\begin{tabular}{|c|c|c|c|c|c|c|c|c|c|c|}
\hline \multicolumn{11}{|c|}{ Table 4: Contd., } \\
\hline 10. & Jharkhand & - & 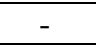 & 2.79 & 2.69 & 2.70 & 2.37 & 2.43 & 2.54 & 2.43 \\
\hline 11. & Jammu \& Kashmir & 0.10 & 2.26 & 1.66 & 1.60 & 1.43 & 1.38 & 1.34 & 1.28 & 1.26 \\
\hline 12. & Karnataka & 2.81 & 2.26 & 4.18 & 3.87 & 3.62 & 3.27 & 3.75 & 3.8 & 4.38 \\
\hline 13. & Kerala & 1.76 & 1.40 & 2.41 & 2.39 & 2.36 & 2.02 & 1.93 & 1.98 & 2.14 \\
\hline 14. & Madhya Pradesh & 11.40 & 7.56 & 4.72 & 4.48 & 4.12 & 4.17 & 4.24 & 4.3 & 4.49 \\
\hline 15. & Maharahashtra & 16.06 & 19.29 & 17.76 & 17.50 & 16.71 & 18.1 & 16.92 & 16.97 & 8.78 \\
\hline 16. & Manipur & 0.28 & 0.05 & 0.04 & 0.03 & 0.04 & 0.03 & 0.03 & 0.04 & 0.05 \\
\hline 17. & Meghalaya & 0.004 & 0.02 & 0.03 & 0.03 & 0.03 & 0.02 & 0.02 & 0.02 & 0.02 \\
\hline 18. & Mizoram & - & 0.01 & 0.04 & 0.04 & 0.04 & 0.05 & 0.05 & 0.06 & 0.07 \\
\hline 19. & Nagaland & 0.15 & 0.16 & 0.13 & 0.12 & 0.10 & 0.08 & 0.07 & 0.07 & 0.06 \\
\hline 20. & Orissa & 6.34 & 6.01 & 4.65 & 4.50 & 4.25 & 5.14 & 5.83 & 5.67 & 6.07 \\
\hline 21. & Punjab & 1.19 & 0.73 & 1.30 & 1.22 & 1.14 & 1.02 & 1.02 & 1.02 & 0.99 \\
\hline 22. & Rajasthan & 1.37 & 2.13 & 2.55 & 2.62 & 2.25 & 2.05 & 1.94 & 2.06 & 2.19 \\
\hline 23. & Sikkim & - & 0.08 & 0.38 & 0.36 & 0.31 & 0.25 & 0.24 & 0.23 & 0.22 \\
\hline 24. & Tamilnadu & 5.39 & 4.76 & 7.55 & 6.66 & 7.40 & 7.15 & 6.84 & 6.51 & 6.09 \\
\hline 25. & Tripura & 0.20 & 0.29 & 0.24 & 0.40 & 0.23 & 0.31 & 0.36 & 0.36 & 0.37 \\
\hline 26. & Telangana & - & - & 0 & - & 0 & 0 & 0 & 0.61 & 0.83 \\
\hline 27. & Uttar Pradesh & 5.35 & 7.30 & 6.64 & 6.77 & 6.46 & 6.4 & 6.24 & 6.22 & 6.44 \\
\hline 28. & Uttaranchal & - & - & 1.98 & 1.88 & 1.86 & 1.49 & 1.44 & 1.39 & 1.39 \\
\hline 29. & West Bengal & 7.07 & 6.57 & 5.10 & 5.10 & 4.93 & 5.15 & 4.87 & 4.8 & 4.54 \\
\hline \multicolumn{11}{|c|}{ Union Territories } \\
\hline 1. & Andaman \& Nicobar Islands & 0.01 & 0.01 & 0.03 & 0.03 & 0.03 & 0.17 & 0.13 & 0.02 & 0.02 \\
\hline 2. & Chandigarh & 0.01 & 0.10 & 0.03 & 0.02 & 0.02 & 0.03 & 0.03 & 0.03 & 0.03 \\
\hline 3. & Dadra Nagarhavli & - & - & 0 & - & 0 & 0.02 & 0.02 & 0.02 & 0.02 \\
\hline 4. & Daman and Diu & - & - & 0 & - & 0 & 0.01 & 0.01 & 0.01 & 0.01 \\
\hline 5. & Delhi & 2.62 & 5.28 & 2.87 & 2.71 & 3.72 & 4.5 & 3.52 & 3.33 & 4.52 \\
\hline 6. & Lakshadweep & - & - & 0 & - & 0 & 0 & 0 & 0 & 0 \\
\hline \multirow[t]{2}{*}{7.} & Pondicherry & 0.02 & 0.03 & 0.01 & 0.03 & 0.03 & 0.02 & 0.02 & 0.02 & 0.02 \\
\hline & Others and Unallocated & 6.70 & 3.82 & 4.60 & 5.32 & 6.88 & 6.27 & 6.25 & 9.74 & 15.79 \\
\hline $\begin{array}{l}\text { Grand } \\
\text { Total }\end{array}$ & All India & 100 & 100 & 100 & 100 & 100 & 100 & 100 & 100 & 100 \\
\hline
\end{tabular}

Notes and Source: Author's calculation based on Table-3.

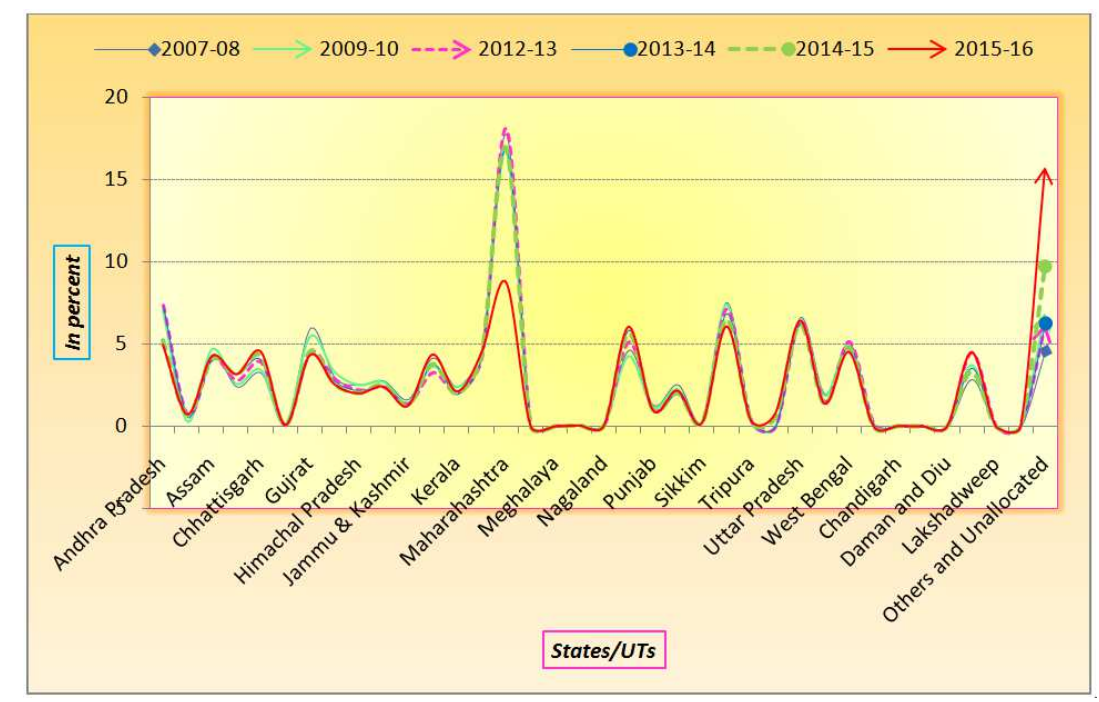

Source: Author's elaboration, based on Public Enterprises Survey 2007/08 to 2015/2016, Govt. of India

Figure 2: Share of States/UTs in Gross Block of CPSEs (Percentage of Total) 
Table 4 and Figure 2 present the share of gross block of CPSEs in several States/ Union Territories of India in terms of percentage for the year 1984-85 to 2015-16. It is clear from the study that in the year 1984-85, the 81.44 percent share of gross block was invested in 10 states of India., viz.,, Maharahashtra, Bihar, Madhya Pradesh, Andhra Pradesh, West Bengal, Orissa, Tamilnadu, Uttar Pradesh, Assam, and Gujrat. These 10 states have the highest share of gross block of CPSEs, which are in decreasing order 16.06 percent, 12.33 percent, 11.4 percent,8.58 percent,7.07 percent,6.34 percent,5.39 percent,5.35 percent,5.18 percent, and 3.74 percent, respectively. In the year 2015-16, the highest share(54.68 percent) of fixed investment in CPSEs was in these 10 states, namely, Maharahashtra(8.78 percent), Uttar Pradesh(6.44 percent), Tamilnadu(6.09 percent), Orissa(6.07 percent), Andhra Pradesh(4.99 percent), Chhattisgarh(4.55 percent), West Bengal(4.55-4 percent), Madhya Pradesh(4.49 percent), Karnataka(4.38 percent), and Gujrat(4.35 percent). During the year 2015-16 in comparison to 1984-85, the Share of gross block has been increased in states, viz., Goa, Gujrat, Haryana, Himachal Pradesh, Jammu \& Kashmir, Karnataka, Kerala, Meghalaya, Rajasthan, Tamilnadu, Tripura, and Uttar Pradesh, while on the other side, share of gross block has been declined in the states like, Andhra Pradesh, Assam, Bihar, Madhya Pradesh, Maharahashtra, Manipur, Nagaland, Orissa, Punjab, and West Bengal. Share of gross block has been increased in Union Territories as well as others and unallocated areas. Andaman \& Nicobar Islands, Chandigarh, Delhi, and others and unallocated areas' share in gross block of CPSEs were raised by 0.01 percent,0.02 percent,1.9 percent, and 9.09 percent, respectively in the year 2015-16 in contrast in 1984-85.

One of the reasons for the decline in the gross block of Andhra Pradesh, Bihar and Madhya Pradesh are that new states, viz., Telangana, Chhattisgarh, and Jharkhand, consecutively have been formed from so-called states. Many CPSEs are located in curved out new states and share of these new states in total gross block in the year 2015-16, were 0.83 percent, 4.55 percent, and 2.43 percent, respectively. In addition, Central Government has also disinvested the equity of several CPSEs in India and at the same time many new CPSEs have been set-up in the nation.

Gross block in CPSEs of 13 industrially backward states, 2industrially developing states are on an average more than 50 percent under the span of study, while on the other hand, share of 7 industrially developed states ison an average higher than 40 percent in the same span out of 36 States/ Union Territories of India. There are lot of difficulties of backward states, which hinders their industrial development. The scarcity of enterprises in various areas of the country is usually depends upon the factors such as the availability of the essential raw materials or other natural resources, sufficient availability of power, water supply and transport facilities which need to develop their sufficiently. For dispersal of industries and setting of units in industrially backward areas Government also provided special concessions and facilities. Comparative statistics of gross block in industrially backward and developing states as well as industrially developed states have been shown in Table 5 as follows:

Table 5: Comparative Statistics of Gross Block in Industrially Back Ward, Developing and Developed States

\begin{tabular}{|c|c|c|c|c|c|c|c|c|c|c|}
\hline \multicolumn{11}{|c|}{$\begin{array}{l}\text { Industrially Back Ward States-Andhra Pradesh, Assam, Bihar, Himachal Pradesh, Jammu \& Kashmir, Madhya Pradesh, } \\
\text { Orissa, Rajasthan, Uttar Pradesh, Chhattisgarh, Jharkhand, Telangana, and Uttaranchal; Industrially Developing States- } \\
\text { Karnataka, and Kerala. }\end{array}$} \\
\hline $\begin{array}{l}\text { S. } \\
\text { No }\end{array}$ & Variables & 1984-85 & 1996-97 & 2007-08 & 2008-09 & 2009-10 & 2012-13 & 2013-14 & 2014-15 & 2015-16 \\
\hline 1. & Total Share & 55.67 & 48.84 & 51.02 & 49.62 & 49.25 & 48.61 & 49.79 & 48.75 & 50.64 \\
\hline 2. & Average & 5.06 & 4.44 & 3.64 & 3.54 & 3.52 & 3.47 & 3.56 & 3.25 & 3.38 \\
\hline 3. & Max. & 12.33 & 7.56 & 6.85 & 6.78 & 7.03 & 7.33 & 7.26 & 6.22 & 6.44 \\
\hline 4. & Min. & 0.1 & 1.4 & 1.66 & 1.6 & 1.43 & 1.38 & 1.34 & 0.61 & 0.83 \\
\hline 5. & S. D. & 4.15 & 2.86 & 1.78 & 1.81 & 1.78 & 1.90 & 1.95 & 1.66 & 1.72 \\
\hline 6. & C. V. & 82.01 & 64.41 & 48.90 & 51.13 & 50.57 & 54.76 & 54.78 & 51.08 & 50.89 \\
\hline
\end{tabular}




\begin{tabular}{|c|c|c|c|c|c|c|c|c|c|c|}
\hline \multicolumn{10}{|c|}{ Table 5: Contd., } \\
\hline \multicolumn{10}{|c|}{ Industrially Developed States-Delhi, Gujrat, Haryana, Maharahashtra, Punjab, Tamilnadu, and West Bengal. } \\
\hline $\begin{array}{c}\text { S. } \\
\text { No }\end{array}$ & Variables & $\mathbf{1 9 8 4 - 8 5}$ & $\mathbf{1 9 9 6 - 9 7}$ & $\mathbf{2 0 0 7 - 0 8}$ & $\mathbf{2 0 0 8 - 0 9}$ & $\mathbf{2 0 0 9 - 1 0}$ & $\mathbf{2 0 1 2 - 1 3}$ & $\mathbf{2 0 1 3 - 1 4}$ & $\mathbf{2 0 1 4 - 1 5}$ & $\mathbf{2 0 1 5 - 1 6}$ \\
\hline 1. & Total Share & 36.94 & 45.23 & 43.53 & 43.05 & 42.66 & 43.29 & 40.22 & 39.8 & 31.84 \\
\hline 2. & Average & 5.28 & 6.46 & 6.22 & 6.15 & 6.09 & 6.18 & 5.75 & 5.69 & 4.55 \\
\hline 3. & Max. & 16.06 & 19.29 & 17.76 & 17.5 & 16.71 & 18.1 & 16.92 & 16.97 & 8.78 \\
\hline 4. & Min. & 0.87 & 0.73 & 1.3 & 1.22 & 1.14 & 1.02 & 1.02 & 1.02 & 0.99 \\
\hline 5. & S. D. & 4.86 & 5.69 & 5.10 & 4.93 & 4.69 & 5.17 & 4.86 & 4.88 & 2.30 \\
\hline 6. & C. V. & 92.05 & 88.08 & 81.99 & 80.16 & 77.01 & 83.66 & 84.52 & 85.77 & 50.55 \\
\hline & $\begin{array}{c}\text { All India- } \\
\text { Total }\end{array}$ & 100 & 100 & 100 & 100 & 100 & 100 & 100 & 100 & 100 \\
\hline & $\begin{array}{c}\text { All India- } \\
\text { Average }\end{array}$ & $\mathbf{3 . 7 0}$ & $\mathbf{3 . 3 1}$ & $\mathbf{2 . 7 2}$ & $\mathbf{3 . 0 3}$ & $\mathbf{2 . 7 0}$ & $\mathbf{2 . 7 0}$ & $\mathbf{2 . 6 5}$ & $\mathbf{2 . 7 0}$ & $\mathbf{2 . 7 0}$ \\
\hline
\end{tabular}

Note and Source: Author's calculation, based on Public Enterprises Survey 1984/85 to 2015/2016, Government of India.

Data of four states, viz., Chhattisgarh, Jharkhand, Telangana, and Uttaranchal are highlighted since 2007-08, 2007-08, 2014-15, 2007-08, and these states are curve out from M. P., Bihar, A. P., and U. P., respectively.

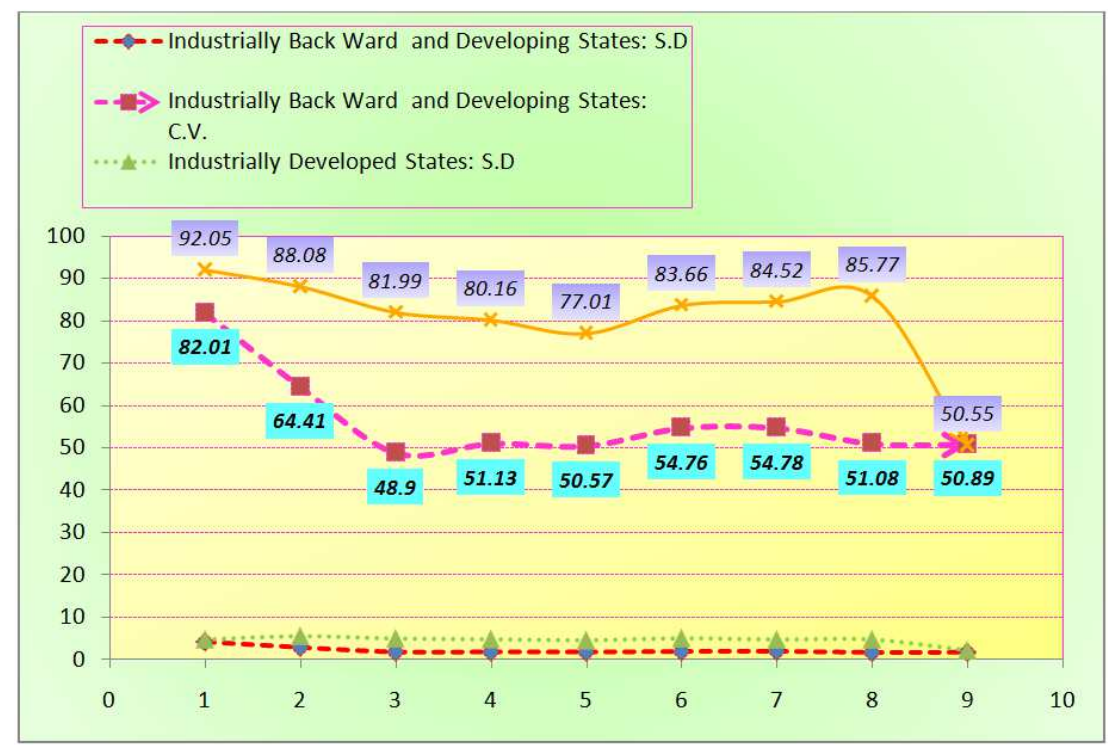

\section{Source: Author's elaboration, based on Public Enterprises Survey 2007/08 to 2015/2016, Govt. of India}

Figure 3: Statistics of Gross Block in Industrially Back Ward, Developing and Developed States

Table 5 and Figure 3 present the statistics, viz., Coefficient of Variation, Standard Deviation, Minimum Value, Maximum Value, Mean share, and total share of 13 industrially backward states, 2 industrially developing states and 7 industrially developed states in India. When we study the participation of states in gross block of CPSEs in terms of average, it is obvious that at the end of the year 1984-85,15 industrially backward and developing states having on an average 5.06 percent and 7 industrially developed states have on an average 5.28 percent share in gross block of CPSEs, which were higher than all India average of 3.70 percent. In the year 2015-16, average share in gross block of so-called industrially backward and developing states as well as industrially developed states decline and reach to 3.38 percent and 4.55 percent, consecutively. All India average has also declined in 2015-16 and reached 2.70 percent.

To the stand points of Coefficient of Variation (C. V.) in terms of relative measure, it has come to the notice that in 1984-85, C. V. of corresponding industrially backward and developing states as well as industrially developed states were 82.01 percent and 92.05 percent, it has lot of declined in 2015-16, reached 50.89 percent and 50.55 percent, 
respectively. It is evident that gross block in industrially backward and developing states are more consistent in contrast to gross block in industrially developed states since 1984-85 to 2014-15. In 2015-16, somewhat equal variability has been seen in both categories of states in coefficient of variation. It is notable here that special provisions in respect of establishing certain undertakings in North-Eastern States U/s 80-IE and 80- IC of Income Tax Act and also provisions are given in Finance Act, 2007.7 north eastern states, viz., Arunachal Pradesh, Manipur, Meghalaya, Mizoram, Nagaland, Sikkim, and Tripura are not comprised in above calculation. Apart from these, States/Union Territories like, Goa, Andaman \& Nicobar Islands, Chandigarh, Dadra Nagarhavali, Daman and Diu, Lakshadweep, Pondicherry, as well as others and unallocated areas have been excluded from its perimeter of calculation due to meagre share and some exceptions.

\section{CONCLUSIONS}

To sum up, there is no doubt that the CPSEs of the country are spread in less developed states industrially. These have made versatile and important contributions to the country's economy and have been successful to a great extent by fulfilling in its objectives. The requirement is that in the future, these CPSEs will work with maximum efficiency, productivity and intelligence. So it can be fully successful in its purpose. The growth in aggregate 'Gross Block' increased in the range of 6\% to13\% during FY 2008-09 to 2016-17 excepting the FY2015-16. Decrease in excepting financial year due to the implementation of Indian Accounting Standards in CPSEs. CPSEs are working mainly in Manufacturing, Processing and Generation Sector, Services, Mining \& Exploration but Agriculture having negligible participation. It has been reflected from study that in the last three years, the 'Gross Block' increase in most of the states. It increased more than $4 \%$ in descending order in Chhattisgarh, West Bengal, Delhi, Karnataka and Madhya Pradesh and between 5\% and 6\% in the same order in Andhra Pradesh, Tamilnadu, Orissa and Uttar Pradesh. Increase in 'Other and Unallocated' were $14 \%$ to $17 \%$. These undertakings have made significant contributions towards achieving self-sufficiency in the country in the various economic sectors as well as balanced regional development in the nation.

\section{REFERENCES}

1. Braj Kishore, “Corporate Private Sector Financing: An Analysis of Capital in India-1951-52 to 1973-74”, Decision, July 1980 .

2. Braj Kishore," Corporate Internal Finance: A study of Overall Trends and Retentions”, Vikalpa, vol. V, No. 3, July 1980.

3. Bureau of Public Enterprises, 'Public Enterprises Survey', Vol. I, 1982-83, Ministry of Finance, New Delhi, p.28.

4. Chatterjee, P., “Working Capital Financing in Public Sector”, ' Financial Express', August 18, 1983.

5. Chopra, R. N., 'Public sector in India: Its Performance Profitability and Industrial Relations '(New Delhi : Intellectual Publishing House ), 1984, pp. 100-101.

6. Committee on Public Undertakings, Fifth LokSabha, $40^{\text {th }}$ Report, p.135.

7. Dobrovolsky, S. P., “Economics of Corporate Internal and External Financing “, Journal of Finance, vol. XXIII, No. 1, March 1968.

8. Dutt, P. K., “Financial Performance of Central Government Public Enterprises”, Economic Times, December 2, 1977.

9. Government of India, Department for Promotion of Industry and Internal Trade, Ministry of Commerce and Industry, 'Industrial Policy Resolution 1956', New Delhi, p.4. 
10. Government of India, Department for Promotion of Industry and Internal Trade, Ministry of Commerce and Industry, 'Industrial Policy Resolution 1973', New Delhi, p.6.

11. Government of India, Department for Promotion of Industry and Internal Trade, Ministry of Commerce and Industry, ' Industrial Policy, 1977, New Delhi, p.7.

12. Government of India, Department for Promotion of Industry and Internal Trade, Ministry of Commerce and Industry, 'Statement on Industrial Policy, 1980, New Delhi, p.8.

13. Mehra, G. (2018). Unemployment: Stumbling Block to Economic Growth. IMPACT: International Journal of Research in Humanities, Arts and Literature, 6(1), 71-78.

14. Government of India, Department for Promotion of Industry and Internal Trade, Ministry of Commerce and Industry, 'Statement on Industrial Policy, 1991, New Delhi, p.12.

15. Government of India, Planning Commission, 'First Five-Year Plan', New Delhi, p.422.; Government of India, Planning Commission, 'Second Five-Year Plan', New Delhi, p.49.

16. Government of India, Planning Commission, 'Eleventh Five-Year Plan', New Delhi, p.42.

17. Kulkarni, P. V., "Financial Management” (Bombay : Himalaya Publishing House, 1981), p.433.

18. P. R. Brahmanandaet. (Editor), 'Indian Economic Development and Policy', by V. K. R. V. rao, New Delhi :Vikas Publishing House, 1976. pp. 25-26.

19. Chaudhary, M. L. (2015). Gross Cost Contract v/s Net Cost Contract: What Should Indian Cities Opt For?. International Journal of Business Management \& Research, ISSN (P), 2249-6920

20. Ramanadham, V. V., 'The Finances of Public enterprises ; Bombay: Asia Publishing House, 1963, p.24

21. Mathur, B. P, "Financing of Public Enterprises in India and the Question of Private Equity Participation”, “Indian Journal of Economics', July 1969, pp.55-75.

22. Minister of Heavy Industries \& Public Enterprises, Government of India, Public Enterprises Survey from 1984-85 to 20172018, Government of India, New Delhi.

23. Ministry of Finance, Department of Economic Affairs, Economic Division, Economic Survey 1984-85 to 2017-2018, Government of India. 